\title{
KEPUASAN PERKAWINAN DITINJAU DARI RELIGIUSITAS PADA PASANGAN INFERTIL DI KELURAHAN SEI SIKAMBING D
}

\author{
Winnie Wibiren \\ Program Studi Psikologi \\ Fakultas Psikologi Universitas Prima Indonesia
}

\begin{abstract}
Abstrak---Penelitian ini bertujuan untuk mengetahui hubungan antara religiusitas dengan kepuasan perkawinan. Hipotesis yang diajukan dalam penelitian ini adalah ada hubungan positif antara religiusitas dengan kepuasan perkiawinan, dengan asumsi semakin tinggi religiusitas maka semakin tinggi kepuasan perkawinan dan sebaliknya semakin rendah religiusitas maka semakin rendah kepuasan perkawinan.Subjek penelitian yang digunakan dalam penelitian ini adalah pasangan suami istri yang belum dikaruniai anak setelah menikah selama 2 tahun, di Kelurahan Sei Sikambing D, yang berjumlah 80 orang / 40 pasangan. Penelitian ini menggunakan metode Purposive Random Sampling. Data diperoleh dari skala untuk mengukur religiusitas dan kepuasan perkawinan.Perhitungan dilakukan dengan melalui uji prasyarat analisis (uji asumsi) yang terdiri dari uji normalitas sebaran dan uji linearitas hubungan. Analisis data yang digunakan adalah menggunakan korelasi Pearson melalui bantuan SPSS 17 for Windows. Hasil analisis data menunjukkan koefisien korelasi sebesar 0,610 dengan $\mathrm{p}$ sebesar $0,000(\mathrm{p}<0,05)$. Ini menunjukkan ada hubungan positif antara empati dengan perilaku prososial. Religiusitas merupakan salah satu faktor yang mempengaruhi perilaku prososial dengan sumbangan $\left(\mathrm{R}^{2}\right)$ sebesar $37.2 \%$ selebihnya $66.8 \%$ dipengaruhi oleh faktor lain yang tidak diteliti. Dari hasil penelitian ini dapat ditarik kesimpulan bahwa hipotesis penelitian ada hubungan positif antara religiusitas dan kepuasan perkawinan, dapat diterima.
\end{abstract}

Keywords: kepuasan perkawinan, religiusitas

\begin{abstract}
This study aims to find out the relationship between marital satisfaction and religiosity. The hypothesis drawn in this study is that there is a positive relationship between religiosity and marital satisfaction, assuming the higher the religiosity, the higher the marital satisfaction and conversely, the lower religiosity, the lower the marital satisfaction. The subjects of this study are the infertile couples that have been married for 2 years, in Kelurahan Sei Sikambing D, as many as 40 couples. Data obtained from the scale to measure religiosity and marital satisfaction. The calculation is performed through the prerequisite test analysis (assumption test) which consists of normality test of distribution and linearity test of relationship.
\end{abstract}


Analysis of the data used is Pearson correlation through SPSS 17 for Windows. The results show the correlation coefficient of 0.610 with $p$ of $0.000(p<0.05)$. It indicates that there is a positive relationship between religiosity and marital satisfaction Religiosity is one of the factors that affected prosocial behavior with the contribution (R2) of $37.2 \%$, and the remaining of $66.8 \%$ is affected by other factors not examined in this study. From these results, it can be concluded that the hypothesis of there is a positive relationship between religiosity and marital satisfaction is acceptable.

Keywords: marital satisfaction, religiosity

\section{PENDAHULUAN}

Setiap pasangan tentu memiliki hasrat untuk hidup berdampingan selamanya dengan pasangan yang dicintainya. Sudah menjadi impian setiap pasangan untuk memiliki rumah tangga yang harmonis dan bahagia. Hasrat tersebut harus diupayakan dan dikokohkan melalui suatu ikatan resmi baik secara hukum maupun secara agama, yang disebut sebagai perkawinan/pernikahan (Kartini Kartono, 1992). Pasangan yang hendak mengikrarkan diri dalam ikatan perkawinan biasanya percaya bahwa pernikahan mereka adalah pernikahan terbaik yang akan terjalin seumur hidup.

Menurut Kartini Kartono (1992), perkawinan adalah suatu peristiwa, di mana sepasang mempelai atau sepasang calon suami-istri dipertemukan secara formal di hadapan penghulu atau kepala agama tertentu, para saksi dan sejumlah hadirin, untuk kemudian disahkan secara resmi sebagai suami-istri dengan upacara dan ritus-ritus tertentu. Peristiwa perkawinan merupakan suatu upacara sakral dan bentuk proklamasi secara resmi sepasang pria dan wanita, yang kemudian berjanji untuk saling memiliki satu sama lain, saling menyayangi, saling membutuhkan, saling memberi motivasi, dan saling menjaga. Kedua pribadi yang memiliki banyak perbedaan tersebut kemudian disahkan menjadi satu pribadi yang utuh. Saat memasuki pernikahan, kepentingan pribadi sudah harus disingkirkan dan digantikan dengan kepentingan bersama, terlebih harus mendahulukan kepentingan pasangan.

Bila kita melihat dalam budaya Indonesia yang kita kenal, ketiadaan anak dalam sebuah pernikahan terkadang menjadi sebuah masalah yang cukup besar. Masalah yang timbul biasanya berupa tekanan sosial, tekanan dari keluarga besar, maupun pengucilan. Tidak jarang pula ditemui bahwa hal tersebut dapat menjadi pemicu timbulnya perceraian. Tidaklah heran bahwa keinginan untuk cepat memiliki anak merupakan salah satu harapan utama setiap pasangan yang sudah menikah.

Sebuah penelitian yang dilakukan oleh Hull dan Tukiran (dalam Demartoto, 2008) juga menyatakan hal senada. Ketiadaan anak dalam sebuah pernikahan dapat menyebabkan hal-hal seperti: (1) perempuan memiliki kemungkinan untuk dipoligami atau diceraikan, (2) pasangan 
yang tak kunjung memiliki anak lebih banyak menghabiskan waktu dan biaya untuk mencoba berbagai pengobatan, dan (3) sumber rasa malu dalam keluarga.

Secara hukum, di dalam Undang- Undang nomor 1 tahun 1974 pasal ke-4, tertulis bahwa suami berhak memiliki istri lebih dari satu apabila istri tidak dapat melahirkan keturunan (www.hukum.unsrat.ac.id). Terbukti bahwa memiliki anak atau keturunan merupakan suatu hal yang sangat penting, bahkan terkesan sangat diharuskan. Seperti yang telah disebutkan sebelumnya, masalah belum memiliki anak juga dapat menyebabkan perceraian. Sangat jarang ditemukan istri yang bersedia bila suaminya memiliki istri lebih dari satu. Bila suami memutuskan untuk beristri lebih dari satu, biasanya istri akan menolak dan mengambil keputusan untuk berpisah. Walaupun ada beberapa kasus ditemukan istri bersedia untuk dipoligami dengan alasan suami ingin mendapatkan keturunan, namun kasus ini sangat jarang ditemukan dan terdengar. Jelaslah bahwa ketiadaan anak dalam sebuah pernikahan dapat menjadi salah satu sumber masalah perceraian.

Kasus ketiadaan anak seperti yang dibahas di atas sering disebut sebagai infertilitas atau ketidaksuburan. Infertilitas di Indonesia terbilang masih cukup tinggi. Terbukti dari hasil survei, seperti yang dilansir dalam sebuah website online, terdapat sekitar 18 persen hingga 20 persen pasangan di Indonesia pada tahun 2011 yang mengalami masalah infertilitas. Fakta tersebut sejalan dengan berkembangnya program kesuburan yang sedang dikembangkan lebih lanjut di Indonesia, yaitu program bayi tabung. Meskipun program ini terbilang cukup mahal, namun peminat program ini tetap saja meningkat (jpnn.com). Menurut statistik prevalensi pada Rumah Sakit Umum Pusat H. Adam Malik, kasus infertil yang terjadi di kota Medan sendiri mencapai angka 17,5 persen pada tahun 2013. Angka ini meningkat sebanyak 5 persen dibandingkan tahun sebelumnya yang hanya mencapai 12 persen (hariansib.co)

Persoalan infertilitas bukanlah hal yang asing terjadi di dalam masyarakat. Sudah banyak kasus-kasus yang terjadi dalam masyarakat, dan tidak jarang juga terdengar kasus perceraian yang disebabkan oleh karena masalah infertilitas. Memang masalah tersebut bukanlah alasan utama, namun turut menjadi akar percekcokan yang akhirnya berujung pada perceraian. Pada sebuah website berita online (www.centroone.com, 2013), dikabarkan bahwa artis Feby Febiola mengalami banyak percekcokan dan sudah jarang terlihat bersama-sama selama beberapa waktu terakhir. Persoalan yang menjadi penyebabnya diketahui karena Feby dan suaminya, Bruce, masih belum memiliki anak setelah 12 tahun menikah. Meskipun Feby enggan mengakuinya, namun ia juga tidak menyanggah pernyataan bahwa dirinya dan suami sering bertengkar karena persoalan belum memiliki anak ini.

Kasus yang sama juga terjadi pada rumah tangga Susan Bachtiar, seorang model, presenter, dan bintang film. Dikabarkan dalam website online kompas, Susan menggugat cerai suaminya, Supardi Supangat, karena sering terjadi pertengkaran di antara keduanya. Pertengkaran yang terjadi dikarenakan banyak hal, salah satunya adalah habisnya kesabaran Susan karena belum juga dikaruniai anak setelah 10 tahun menikah, namun sang suami tidak mau memeriksakan dirinya ke dokter. Pertengkaran dan tekanan dari masyarakat yang dialami Susan selama menjalin rumah tangganya membuat Susan memutuskan untuk mengakhiri pernikahannya selama 10 tahun itu pada tahun 2010 ( kompas.web.id) 
Perceraian yang terjadi dalam sebuah pernikahan merupakan sebuah indikator yang menunjukkan bahwa salah seorang atau mungkin kedua belah pihak tidak puas atas pernikahan mereka (Alpenia, 2012). Menurut Hendrick \& Hendrick (1992), kepuasan perkawinan adalah kebahagiaan dalam pekawinan, kesepakatan akan nilai-nilai yang ada, prioritas dan peraturan keluarga bagi pasangan dalam perkawinan, keterlibatan emosional dengan anak-anak, dan berbagai perasaan lain, ekspresi verbal dan tingkah laku yang menjadi ciri evaluasi dari suatu hubungan,

Kepuasan perkawinan seseorang akan terpenuhi bila kebutuhan, harapan, dan keinginan seseorang terpenuhi. Pandangan individu terhadap kehidupan pernikahannya menjadi sebuah penilaian dasar mengenai terpenuhinya hal tersebut. Apabila yang diinginkan, diharapkan, dan dibutuhkan terpenuhi sesuai dengan persepsi individu tersebut, maka dapat diduga kepuasan perkawinannya juga tinggi (dalam Wismanto, 2011). Kepuasan perkawinan yang tinggi mampu mempertahankan perkawinan dalam jangka waktu yang lama (atau mungkin selamanya), dan mencegah perceraian, meskipun banyak sekali tantangan dan hambatan yang terjadi dalam rumah tangga.

Menurut Hosseini (2013), salah satu faktor yang dapat mempengaruhi kepuasan perkawinan adalah religiusitas. Religiusitas dianggap memiliki peran penting karena dipercaya dapat mempengaruhi pola pikir serta perilaku pasangan dalam menjalani kehidupan pernikahan. Wallerstein and Blakeslee (dalam Knox \& Schacht, 2010) meneliti lima puluh pasangan yang bahagia dan stabil (dari sepuluh hingga lima puluh tahun). Hasilnya menyatakan bahwa pernikahan yang dianggap bahagia memiliki anak sekurang-kurangnya satu anak.

Religiusitas didefinisikan sebagai suatu perasaan, tindakan, dan pengalaman individuindividu dalam kesepiannya, sepanjang mereka melihat dirinya berhadapan dalam hubungan dengan apa yang dianggapnya sebagai Tuhan (James, dalam Rakhmat, 2013). Menurut Herbert Spencer, religiusitas berarti sebuah pengakuan akan adanya kekuatan yang melebihi kekuatan dirinya yang melampaui pengetahuan manusia (Rakhmat, 2013). Individu yang memiliki tingkat religiusitas yang tinggi dipercaya mempunyai kendali yang lebih tinggi terhadap perilakunya, berkaitan dengan segala konsekuensi yang akan diterima seseorang dalam melakukan sesuatu.

Terdapat beberapa ahli yang telah meneliti dan menunjukkan hasil-hasil penelitian yang berkaitan dengan variabel keduanya. Salah satunya adalah penelitian yang dilakukan oleh Zahrotun dan koleganya (2012) terhadap 125 pasangan suami istri di Jakarta. Hasilnya menunjukkan bahwa sebesar 15 persen variabel religiusitas mempengaruhi kepuasan perkawinan. Penelitian selanjutnya juga dilakukan oleh Khalatbari, dkk. pada tahun 2013, yang melakukan penelitian dengan menyebarkan 200 kuisioner pada pasangan yang telah menikah berumur antara 20-50 tahun di Imam Sadegh University. Hasil penelitian membuktikan bahwa sebesar 6,15 persen variabel religiusitas mampu membuat ketenangan emosional yang juga dapat menolong mereka mengatasi persoalan perkawinan dan meningkatkan kepuasan perkawinan.

Masih ada penelitian lainnya yang juga mendukung penelitian yang dilakukan oleh Zahrotun dan Khalatbari. Penelitian tersebut dilakukan oleh Hosseini, dkk. pada tahun 2013. Hasil penelitian yang mereka lakukan membuktikan bahwa sebesar 10 persen variabel perilaku dan orientasi keagamaan mempengaruhi kepuasaan perkawinan. Religiusitas yang dimiliki dalam sebuah perkawinan membuat seseorang mampu mengendalikan segala tingkah lakunya. 
Selain religiusitas, kepuasan perkawinan dapat dipengaruhi oleh penyesuaian perkawinan. Penyesuaian perkawinan adalah proses membiasakan diri pada suatu kondisi baru dan berbeda sebagai hubungan suami istri dengan harapan bahwa mereka akan menerima tanggung jawab dan memainkan peran sebagai suami istri. Sebuah penelitian dilakukan oleh Rachmawati dan Mastuti (2013) pada 52 orang istri dari anggota Brigif Marinir TNI AL di Surabaya. Pasangan ini menjalani perkawinan jarak jauh (long distance marriage) karena pekerjaan sang suami mengharuskan mereka untuk berpisah selama masa bertugasnya, yang bisa mencapai bulanan hingga tahunan. Hasil penelitian tersebut menunjukkan bahwa istri dengan penyesuaian yang tinggi memiliki kepuasan perkawinan yang lebih tinggi pula, dibandingkan dengan istri yang memiliki penyesuaian diri rendah.

Kepuasan perkawinan juga dapat dipengaruhi oleh kepribadian. Sebuah penelitian membuktikan bahwa kepribadian ekstraversi mampu mempengaruhi kepuasan perkawinan. Penelitian yang dimaksud tersebut dilakukan oleh Sari dkk. (2011), yang melakukan penelitian pada 68 wanita di PT Indotama Omicron Kahar, dengan hasil yang menunjukkan bahwa variabel kepribadian ekstraversi memberikan sumbangan 9,5 persen pada variabel kepuasan perkawinan. Hal ini disebabkan karena orang dengan kepribadian ekstraversi tinggi mampu bersosialisasi dengan baik sehingga mereka tidak merasa terisolasi dan kesepian. Mereka juga mempunyai kepercayaan diri yang tinggi yang mempermudah mereka menyelesaikan suatu masalah. Kebanyakan dari mereka memiliki daya saring yang sangat baik terhadap efek negatif dari stres. Orang dengan tingkat ekstraversi tinggi memiliki keyakinan bahwa sebuah masalah bukanlah ancaman, melainkan tantangan.

\section{METODE PENELITIAN}

\section{Partisipan}

Populasi dalam penelitian ini adalah pasangan suami istri yang belum memiliki anak di Kelurahan Sei Sikambing D yang berjumlah 180 orang atau 90 pasangan. Jumlah sampel yang diteliti dalam penelitian ini sebanyak 80 orang atau 40 pasangan. Karakteristik yang akan digunakan dalam penelitian ini adalah: pasangan suami istri yang sah baik secara hukum maupun agama, telah menikah setidaknya selama 2 tahun, belum memiliki anak, yang bukan dikarenakan alasan kesehatan atau suatu komitmen tertentu, dan memeluk sebuah agama tertentu.

\section{Desain}

Metode penelitian ini menggunakan pendekatan kuantitatif, berupa metode testing dengan alat ukur berupa skala. Metode yang digunakan dalam penelitian ini adalah pembagian skala Kepuasan Perkawinan dan skala Religiusitas. Jenis skala yang digunakan adalah skala Likert.

\section{Teknik Pengumpulan Data}

Skala Kepuasan Perkawinan disusun memakai acuan alat ukur ENRICH Marital Scale (Olson, 1993), dengan dimensinya: (1) personality issue, (2) communication, 3) conflict 
resolution, (4) financial management, (5) leisure activities, (6) sexual relationship, (7) children and parenting, (8) family and friends, (9) equalitarian roles, dan (10) religion orientation. Sedangkan, skala Religiusitas yang digunakan dalam penetitian ini adalah disusun berdasarkan aspek-aspek religiusitas menurut Glock, dkk (dalam Louwenthal, 2000), yaitu: (a) Dimensi Ideologi atau keyakinan, (b) Dimensi Peribadatan, (c) Dimensi Penghayatan, (d) Dimensi Pengetahuan, (e) Dimensi Pengamalan.

\section{Teknik Analisis}

Metode analisis data menggunakan korelasi Product Moment (Pearson Correlation) dengan bantuan SPSS 17.00 for windows untuk mengetahui bagaimana hubungan antara variabel kepuasan perkawinan dengan religiusitas.

\section{ANALISIS DAN HASIL}

Sebelum dilakukan analisis Product Moment (Pearson Correlation), data yang terkumpul terlebih dahulu ditentukan normalitas sebaran dan linieritas hubungannya. Dari uji normalitas dan uji linieritas diketahui bahwa hasilnya memenuhi asumsi tersebut. Hasil uji normalitas sebaran dan uji linieritas hubungan dapat dilihat pada Tabel 1 dan Tabel 2 yaitu sebagai berikut.

Tabel 1 Hasil Uji Normalitas

\begin{tabular}{|l|c|c|c|c|c|}
\hline Variabel & SD & $\begin{array}{c}\text { KS- } \\
\mathbf{Z}\end{array}$ & Sig. & $\mathbf{P}$ & Keterangan \\
\hline Religiusitas & 4.149 & 0.959 & 0,062 & $\mathrm{P}>0,05$ & $\begin{array}{c}\text { Sebaran } \\
\text { normal }\end{array}$ \\
\hline $\begin{array}{l}\text { Kepuasan } \\
\text { Perkawinan }\end{array}$ & 4.108 & 1.179 & 0.158 & $\mathrm{P}>0,05$ & $\begin{array}{c}\text { Sebaran } \\
\text { normal }\end{array}$ \\
\hline
\end{tabular}

Tabel 2. Hasil Uji Linieritas Hubungan

\begin{tabular}{|c|c|c|c|}
\hline Variabel & F & Sig & Keterangan \\
\hline $\begin{array}{c}\text { Religiusitas } \\
\text { Kepuasan Perkawinan }\end{array}$ & 52.270 & 0,000 & Linier \\
\hline
\end{tabular}

Berdasarkan table diatas dapat dikatakan bahwa variabel religiusitas dan kepuasan perkawinan memiliki hubungan linear. Hal ini terlihat dari nilai $\mathrm{P}$ yang diperoleh yaitu 0,000 ( $\mathrm{p}<0,05)$, maka dapat disimpulkan adalah kedua variabel memiliki hubungan linear dan telah memenuhi syarat untuk dilakukan analisa korelasi Pearson Product Moment.

Setelah uji asumsi di terima selanjutnya dilakukan uji hipotesis. Hipotesis dalam penelitian ini adalah hubungan positif antara religiusitas dan kepuasan perkawinan. Berdasarkan tujuan penelitian maka dilakukan uji Pearson Correlation. Hasil uji statistik dapat dilihat pada tabel 3 . 
Tabel 3. Korelasi Antara Religiusitas dengan Kepuasan Perkawinan

\begin{tabular}{|c|c|c|}
\hline Analisis & Pearson Correlation & Signifikansi (p) \\
\hline Korelasi & 0,610 & 0,000 \\
\hline
\end{tabular}

Berdasarkan hasil analisis korelasi antara religiusitas dengan kepuasan perkawinan, diperoleh koefisien korelasi product moment sebesar 0,690dengan p sebesar 0,000 ( $\mathrm{p}<0,05)$. Hal ini menunjukkan bahwa adanya korelasi positif antara religiusitas dengan kepuasan perkawinan, dan hubungan ini berada pada rentang 0,60-0,799, sehingga dikategorikan hubungan yang kuat (Priyatno, 2010).

Berdasarkan hasil perhitungan tersebut, maka hipotesis yang diajukan dalam penelitian ini menunjukkan ada hubungan positif antara religiusitas dengan kepuasan perkawinan pada pasangan suami istri yang mengalami infertilitas, dan dapat dinyatakan bahwa ada hubungan positif antara religiusitas dengan kepuasan perkawinan.

Tabel 4. Model Summary Sumbangan Efektif

\begin{tabular}{|c|c|c|c|c|}
\hline Model & $\mathbf{R}$ & R Square & $\begin{array}{c}\text { Adjusted } R \\
\text { Square }\end{array}$ & $\begin{array}{c}\text { Std. Error of } \\
\text { the Estimate }\end{array}$ \\
\hline 1 & .610 & .372 & .364 & 3.276 \\
\hline
\end{tabular}

Berdasarkan tabel 4 di atas, dapat disimpulkan dalam penelitian ini diperoleh koefisien determinasi sebesar 0,372. Berdasarkan hasil tersebut, dapat disimpulkan bahwa sumbangan 37,2 persen religiusitas mempengaruhi kepuasan perkawinan dan selebihnya 62,8 persen dipengaruhi faktor lain, seperti kepribadian, pendidikan, resolusi konflik, dan komunikasi yang baik. Dengan demikian, dapat disimpulkan bahwa semakin tinggi religiusitas dalam sebuah perkawinan, maka semakin tinggi kepuasan perkawinan. Sebaliknya, semakin rendah religiusitas, maka akan semakin rendah juga kepuasan perkawinan.

\section{DISKUSI}

Penelitian pada 40 pasangan suami istri (80 orang) yang mengalami infertilitas di Kelurahan Sei Sikambing D, maka diperoleh hasil bahwa ada hubungan positif antara religiusitas dengan kepuasan perkawinandengan koefisien korelasi product moment sebesar $\mathrm{r}=0,610$ yang berada pada rentang 0,60-0,799 sehingga dikategorikan memiliki hubungan yang kuat dan nilai $\mathrm{p}$ sebesar 0,000 , ( $\mathrm{p}<0,05)$ yang artinya semakin tinggi tingkat religiusitas pasangan suami istri, maka akan semakin tinggi juga tingkat kepuasan perkawinan, dan juga sebaliknya, semakin rendah tingkat religiusitas, maka akan semakin rendah kepuasan perkawinan.

Hasil dari penelitian ini diperoleh koefisien determinasi $\left(\mathrm{R}^{2}\right)$ sebesar 0,372 Berdasarkan hasil tersebut, dapat disimpulkan bahwa 37,2 persen variabel religiusitas mempengaruhi 
kepuasan perkawinan, dan selebihnya 62,8 persen dipengaruhi oleh faktor lain seperti kepribadian, pendidikan, resolusi konflik dan komunikasi yang baik.

Religiusitas yang tinggi akan cenderung memberikan efek yang positif pada individu. Religiusitas dipercaya dapat memberikan ketenangan batin, cara pandang yang positif, dan motivasi hidup yang kuat bagi siapa saja yang mengalami permasalahan, termasuk pada permasalahan pernikahan. Permasalahan pernikahan yang dapat diselesaikan dengan baik akan menimbulkan kepuasan perkawinan yang tinggi.

Menyambung pernyataan di atas, peneliti juga telah melakukan sedikit wawancara kepada salah seorang subjek wanita yang memilliki infertilitas. Menurut penuturan subjek, ia dan suaminya merasa bahagia meskipun belum dikaruniai anak. Alasan utamanya adalah komitmen antara dirinya dan suami, namun kontribusi religiusitas juga memiliki peran yang tak kalah penting. Subjek mengaku sering ke Gereja setiap Minggu, mengikuti pertemuan-pertemuan, dan berdoa di rumah. Inilah sebabnya subjek memiliki hati yang damai meskipun banyak pihak yang terus mendesak dan menanyakan kapan ia dan suami dikaruniai anak. Ia juga tampak optimis ketika peneliti bertanya mengenai perasaannya dalam menantikan anak dalam pernikahan mereka. Beliau dan suami memiliki harapan yang kuat kepada Tuhan mereka akan kehadiran anak di dalam pernikahan.

Hal ini didukung oleh pernyataan Ahmadi (2008) yang menyatakan bahwa religiusitas dan persamaan ideologi pasangan suami istri dapat menjadicara dalam mencegah ketidakpuasan perkawinan, maupun metode yang bagus dalam menghadapi masalah dalam perkawinan, seperti infertilitas. Aisia (dalam Hidayah, 2005) menyatakan bahwa infertilitas dapat mengakibatkan stress yang cukup berat sehingga mempengaruhi kepuasan perkawinan, namun Clayton (dalam Hidayah, 2005) menyambung apabila diimbangi oleh persamaan ideologi, maka kepuasan perkawinan tetap dapat dijaga bahkan ditingkatkan.

Hasil penelitian yang dilakukan oleh Zahrotun (2012) menyatakan bahwa religiusitas memiliki sumbangsih pada variabel kepuasan perkawinan. Dikatakan bahwa seorang istri yang berada dalam lingkungan keluarga yang agamis, akan mendapatkan kesempatan untuk memperdalam ilmu agama. Sehingga fitrahnya sebagai manusia untuk beriman kepada Allah akan lebih sadar akan konsekuensi yang akan diterima akibat perilakunya. Dengan kata lain, individu dengan religiusitas yang tinggi akan lebih menjaga tingkah lakunya karena akan selalu diingatkan oleh ajaran agama yang dianutnya. Hal tersebutlah yang memungkinkan seseorang merasa lebih puas terhadap pernikahannya. Contohnya, seseorang yang religiusitasnya tinggi akan lebih menjaga tingkah lakunya agar tidak menyakiti perasaan pasangannya. Zahrotun (2012) juga memaparkan bahwa seharusnya agama dijadikan landasan dalam berperilaku dan bertindak, khususnya dalam menghadapi masalah perkawinan, termasuk masalah infertilitas, agar kelanggengan dan keharmonisan rumah tangga dapat terus terjaga.

Religiustias juga sangat efektif dalam menyelesaikan konflik rumah tangga. Menurut Fard (2012), religiusitas mempersiapkan sebuah panduan mengenai kehidupan, dan jika manusia mampu mengikuti panduan tersebut, kesatuan pernikahan dapat semakin dikuatkan. Panduan kehidupan tersebut juga termasuk di dalamnya, cara menyingkirkan konflik pernikahan (Mahoni, dalam Fard, 2012). Beberapa penelitian (Russ, Westfield, \& Ansli, dalam Fard, 2012) juga menunjukkan bahwa mempercayai sebuah kepercayaan religius dapat memperkuat hubungan antar kedua pasangan. Ketika sebuah konflik dalam pasangan terjadi, terutama pada sebuah masalah spesifik, religiusitas dapat menyingkirkan kesalahpahaman dengan mengacu pada konsep spiritual dan nilai-nilai religiusitas yang dianut keduanya. Kesalahpahaman yang 
terselesaikan dengan baik akan meningkatkan kepuasan perkawinan dalam sebuah kehidupan pernikahan. Pernyataan di atas dibenarkan juga oleh pengakuan oleh salah satu subjek wanita yang diwawancara oleh peneliti. Subjek mengaku, ketika ia dan pasangannya bertengkar, ia selalu merasa bersalah kepada Allah karena tidak menjadi suami yang baik bagi istrinya. Perasaan tersebut meluluhkan hati subjek dan membuat subjek selalu ingin menyelesaikan perselisihan di antara mereka.

Berdasarkan pembahasan tersebut di atas, maka dapat disimpulkan bahwa religiusitas dapat meningkatkan kepuasan perkawinan dengan cara memberikan ketenangan batin, menjaga perilaku, memberikan motivasi, dan cara pandang yang lebih positif.

\section{KESIMPULAN}

Berdasarkan hasil-hasil yang telah diperoleh dalam penelitian ini, maka dapat disimpulkan sebagai berikut:

1. Ada hubungan positif antara religiusitas dengan kepuasan perkawinan pada pasangan infertil dengan korelasi Product Moment (r) sebesar 0,610 dengan p sebesar 0,000 ( $\mathrm{p}<0,05)$, artinya semakin tinggi religiusitas maka akan semakin tinggi juga kepuasan perkawinan, dan sebaliknya, semakin rendah religiusitas maka akan semakin rendah juga kepuasan perkawinan.

2. Mean dari religiusitas pada subjek penelitian pasangan suami istri Kelurahan Sei Sikambing D secara keseluruhan menunjukkan bahwa religiusitas subjek penelitian lebih tinggi daripada populasi pada umumnya. Hal ini dapat dilihat dari nilai mean empirik sebesar 115,11 lebih tinggi dari mean hipotetik yaitu 75. Berdasarkan kategori, maka dapat dilihat bahwa keseluruhan subjek yaitu 80 orang memiliki religiusitas tinggi, dan tidak ada subjek yang memiliki religiusitas rendah maupun sedang.

3. Mean dari kepuasan perkawinan pada subjek penelitian pasangan suami istri Kelurahan Sei Sikambing D secara keseluruhan menunjukkan bahwa kepuasan perkawinan subjek penelitian lebih tinggi daripada populasi pada umumnya. Hal ini dapat dilihat dari nilai mean empirik sebesar 117,31 lebih besar dari mean hipotetik yaitu 17,5. Berdasarkan kategori, maka dapat dilihat bahwa terdapat 1 subjek yang memiliki kepuasan perkawinan yang sedang, dan 79 subjek yang memiliki kepuasan perkawinan yang tinggi.

4. Hasil penelitian ini menunjukkan bahwa sumbangan yang diberikan variabel religiusitas terhadap kepuasan perkawinan adalah sebesar 37,2 persen, selebihnya 66,8 persen dipengaruhi oleh faktor lain yang tidak diteliti seperti kepribadian, pendidikan, kehadiran anak, resolusi konflik dan komunikasi yang baik.

\section{SARAN}

Dari kesimpulan yang telah dikemukakan, maka peneliti mengemukakan beberapa saran yang diharapkan akan berguna untuk kelanjutan studi korelasional ini. 
Saran Bagi Pasangan Suami Istri

Berdasarkan penelitian yang telah dilakukan maka disarankan agar mempunyai dasar agama yang kuat dan pandangan ideologi yang sama sebagai fondasi yang kuat dalam membangun kehidupan rumah tangga yang lebih baik.

Saran Kepada Peneliti Selanjutnya

Berdasarkan penelitian yang telah dilakukan maka disarankan untuk meneliti faktor lain, seperti komunikasi, pendidikan, dan sebagainya yang dapat mempengaruhi kepuasan perkawinan, untuk memperbaiki hasil penelitian yang lebih baik.

\section{DAFTAR PUSTAKA}

Dermatoto. 2008. Penelitian Dampak Infertilitas Terhadap Perkawinan. Surakarta

Hendrick \& Hendrick. 1992. Liking, Loving, and Relating $2^{\text {nd }}$ Ed. California: Brooks Company Pacific Grove

Hosseini, F., Saadat, S., dan Jahangiri, S., 2013. The relationship between religious attitudde and marital satisfaction among married personnel of departments of education in Rahst City, Iran. International Journal of Advanced Studies in Humanities and Social Science volume 1 issue 6, 608-615 (diakses tanggal 28 Maret 2015)

Kartono, K. 1992. Psikologi Wanita jilid 1. Bandung: CV Bandar Maju

Knox, D. \& Schacht, C. 2010. Choices in Relationship: An Introduction to Marriage and Family 10 ${ }^{\text {th }}$ Edition. Wadsworth, Candage Learning (diakses tanggal 19 Juni 2015)

Loewenthal, Kate M. 2000. The Psychology of Religion: A Short Introduction. England: Oneworld Publications. ISBN: 978-1-85168-212-6 (diakses tanggal 10 Juni 2015)

Olson, D., DeFrain, J., dan Skogrand, L., 2010. Marriages and Families: Intimacy, Diversity, and Strenght $7^{\text {th }}$ ed. New York: McGraw Hill. Humanities Social Science Language (diakses tanggal 20 Febuari 2015)

Rakhmat, J. 2003. Psikologi Agama: Sebuah Pengantar. Bandung: PT Mizan Pustaka

Sari, A.H. 2011. Pengaruh Kemampuan Komunikasi dan Kemampuan Memecahkan Masalah Terhadap Kepuasan Pernikahan Wanita yang Melakukan Pernikahan Dini. Jurnal Psikologi Fakultas Psikologi Universitas Islam Negeri Syarif Hidayahtullah. (diakses tanggal 18 Febuari 2015) 
Sari, E. I., 2012. Hubungan Antara Kepribadian Ekstraversi Dengan Kepuasan Perkawinan Pada Karyawan Wanita di PT Indotama Omicron Kahar - Purworejo. Jurnal Psikologi Pendidikan dan Perkembangan Volume 02, No. 01. Univeritas Diponegoro (diakses tanggal 18 Febuari 2015)

Wismanto, Y. Bagus. 2012. Multi Faktor yang Mempengaruhi Kepuasan Pasangan Perkawinan di Jawa Tengah. Psychology Journal. Psychology Faculty of Soegijapranata Catholic University Semarang. (diakses tanggal 27 Maret 2015)

Zahrotun. N., Adriani. Y., dan Wahyuni. I. Z.,2012. Peran Religiusitas dan Faktor-Faktor Psikologis Terhadap Kepuasan Pernikahan. Jurnal Psikologi Vol. 53. No. 27 (diakses tanggal 20 Januari 2015) 